\title{
SOME RESULT OF QUALITY PARAMETERS OF "GARDI" TRANSDERMAL PATCH
}

\author{
Erdenechimeg Ch. *, Uuganbayar B., Dejidmaa B., Chimedragchaa Ch., Munkhzul G. \\ Institute of Traditional medicine and Technology, Ulaanbaatar, Mongolia \\ *corresponding author, e-mail: michika_9@yahoo.com
}

ARTICLE INFO: Received: 10 Nov, 2017; Revised: 21 Dec, 2017; Accepted: 25 Dec, 2017

\begin{abstract}
The aim of this study was to conduct standardization study and determine quality parameters of "Gardi" transdermal patch. We used "Gardi" transdermal patch consists of extract of radix Aconitum Kusnezoffii, extract of Terminalia chebula, extract of Saussurea lappa L., extract of Acorus calamus L. and Musk of Musk deer. We used some biologically active compounds of the transdermal patch were revealed by TLC. And main biologically active compounds content of the transdermal patch were determined by spectrophotometric methods. The moisture, average weight and parameters of microbiology were determined by Mongolian National First Pharmacopoeia methods. The transdermal patch was light brown colour, unusual smell and rectangular shape.

We determined aconitine, costunolide and gallic acid in "Gardi" transdermal patch by TLC. The retention time of aconitine was $63.04 \pm 0.2$ minutes and amount was $0.169 \pm 0.009 \%$ by HPLC.

The polyphenolic compounds by spectrophotometer method using Folin-Chiocalto reagent as $0.567 \pm 0.043 \%$. Quality and safety parameters of "Gardi" transdermal patch determined as: moisture $27.28 \pm 0.65 \%$, average weight $3.969 \pm 0.196 \mathrm{~g}$, thickness $0.83 \pm 0.2 \mathrm{~mm}$, total bacteria 1x103, mould, Escherichia coli, Salmonella, Pseudomonas aeruginosa, Staphylococcus aureus and Enterobacter were not detected in "Gardi" transdermal patch.
\end{abstract}

Keywords: Gardi patch; transdermal patch; standardization; quality parameters; high performance liquid chromatography; aconitine;

\section{INTRODUCTION}

Gardi-5 is one of the traditional Mongolian herbal medicines consisting of five herbal medicines: radix Aconitum Kusnezoffii, fruit Terminalia chebula, radix Saussurea lappa L., radix Acorus calamus L. and Musk of Musk deer.

Garidi-5 has been used in traditional Mongolian medicine as an antibacterial and analgesic agent for treatments of various diseases including typhus, diphtheria, joint conditions, neurological and skin disorders [1, 2].

Nowadays, the pharmacological and chemical research of Gardi-5 traditional prescription has been widely researched. The Gardi-5 traditional prescription have been anti-inflammatory and analgesic effects and determined quality control parameters $[3,4]$.

Based on the results of these studies, there is a need to develop new forms of medicine for treatment in the arthritis. Therefore, selecting the "Gardi-5" prescription was made to simplify the process of technological development and application, and to prepare Gardi transdermal patch from Gardi-5 traditional prescription.

At the same time, it was necessary to 
standardize it, and this study was objected to define some quality parameters of the Gardi

\section{MATERIAL AND METHODS}

This study was carried out at Institute of Traditional Medicine and Technology. We used Gardi transdermal patch prepared from the Gardi-5 prescription. Gardi patch is composed extracts of the five herbs including Terminalia chebula Retz., Aconitum Kusnezofii Reichb., Acorus calamus L., Saussurea lappa L., and musk of Moschus moschiferus.

We used some biologically active compounds of the transdermal patch were revealed by TLC.

Determine alkaloid: To $1 \mathrm{~g}$ of the patch add 2-3 drop ammonia and $10 \mathrm{ml}$ petroleum ether for 30 minutes, filter and use the filtrate as the test solution. Dissolve aconitine standard substance in ethanol to produce a solution containing $4 \mathrm{mg}$ per $\mathrm{ml}$ as the reference solution. Carry out the method for TLC, using silica gel $G$ as the coating substance and a mixture of hexane, ethyl acetate, methanol (6.4:3.6:2) as the mobile phase. After develop and removal of the plate, dry in air. Spray with Dragendorff reagent [6].

Determine costunolide: To $0.5 \mathrm{~g}$ of the patch add $10 \mathrm{ml}$ ethylacetate for 30 minutes, filter and use the filtrate as the test solution. Dissolve costunolide standard substance in ethanol to produce a solution containing 4 $\mathrm{mg}$ per $\mathrm{ml}$ as the reference solution. Carry out the method for TLC, using silica gel $\mathrm{G}$ as the coating substance and a mixture of toluene, ethyl acetate $(9.5 ; 0.5)$ as the mobile phase. After develop and removal of the plate, dry in air. Spray with a $2 \%$ of vanillin and sulfuric acid in ethanol and heat at 100-1050C [4].

Determine gallic acid: To $1 \mathrm{~g}$ of the patch add $10 \mathrm{ml} 70 \%$ ethanol, $10 \mathrm{ml}$ ethylacetate for 30 minutes, filter and use the filtrate as the test solution. Dissolve gallic acid standard substance in ethanol to produce a solution containing $4 \mathrm{mg}$ per $\mathrm{ml}$ as the reference solution. Carry out the method for TLC, using patch.

silica gel $G$ as the coating substance and a mixture of benzene, ethyl acetate, formic acid, acetone $(5 ; 5 ; 2 ; 0.5)$ as the mobile phase. After develop and removal of the plate, dry in air. Spray with a $2 \%$ of iron trichloride in ethanol [6].

Estimation of total polyphenolic compounds: The amount of total phenolics was determined according to the FolinCiocalteu procedure. The Folin-Ciocalteu reagent (diluted 1:10 in water) and aqueous $\mathrm{Na} 2 \mathrm{CO} 3(10.75 \%)$ were successively added to the extract. The mixture was at $30 \mathrm{~min}$, then reading absorbance at $760 \mathrm{~nm}$. Gallic acid was used to establish the calibration curve, and total polyphenolic content was expressed as percentage $[7,8]$.

HPLC method: We used ODS C18 column $(4 \times 250 \mathrm{~mm}, 5 \mu \mathrm{m})$, a mixture of acetonitrile and tetrahydrofuran $(25: 15)$ as the mobile phase $\mathrm{A}$ and a $0.1 \mathrm{~mol} / \mathrm{l}$. solution of ammonium acetate (add $0.5 \mathrm{ml}$ of acetic acid per $1000 \mathrm{ml}$ ) as the mobile phase B, elute in gradient as the following: at 0-48 minutes mobile phase A is $15-26 \%$, mobile phase $\mathrm{B}$ is $85-74 \%$, at the $48-49$ minutes mobile phase $\mathrm{A}$ is $26-35 \%$, mobile phase $\mathrm{B}$ is $74-65 \%$, at the $49-58$ minutes mobile phase $\mathrm{A}$ is $35 \%$, mobile phase is $65 \%$, at the $58-65$ minutes mobile phase is $35-15 \%$, mobile phase is $65-85 \%$. As detector a spectrophotometer set at $235 \mathrm{~nm}$. Dissolve a quantity of aconitine in a mixture of isopropanol and chloroform (1:1) to produce a mixture containing $0.1 \mathrm{mg}$ per $\mathrm{ml}$ as the reference solution.

Weight accurately $2 \mathrm{~g}$ of the patch, add 7 $\mathrm{ml}$ of ammonia and $100 \mathrm{ml}$ of a mixture of isopropanol and ethylacetate (1:1) and weight. Ultrasonicate for 30 minutes, then filter. The filtrate evaporate to dryness under reduced pressure below 400C. Dissolve exactly the residue in $15 \mathrm{ml}$ of the mixture of isopropanol 
and chloroform (1:1), filter and use as the test solution.

\section{Physicochemistry parameters: The}

moisture, average weight and parameters of microbiology were determined by Mongolian National First Pharmacopoeia methods [5].

\section{RESULTS}

\section{Result of Thin layer chromatography}

Qualitative test of Gardi patch have been done by thin layer chromatography. The medicinal plant species of Aconitum are a rich source of alkaloids and flavanoids, many of which exhibit broad spectrum of activity [9]. The alkaloids benzoylmesaconine, mesaconitine, aconitine, hypaconitine, heteratisine, heterophyllisine, heterophylline, heterophyllidine, atidine, isotisine, hetidine, hetsinone and benzoylheteratisine have been isolated from tuberous roots of genus Aconitum [10]. We detected aconitine alkaloids in Gardi patch by HPLC and TLC.

In Terminalia chebula, $33 \%$ of the total phytoconstituents are hydrolysable tannins (which may vary from 20-50\%) and are responsible for pharmacological activity.
These tannins contain phenolic carboxylic acid like gallic acid, ellagic acid, chebulic acid and gallotannins such as 1,6 di-O-galloyl- $\beta$ D-glucose, 3,4,6 tri-O-galloyl- $\beta$-D-glucose, 2,3,4,6 tetra-O-galloyl- $\beta$-D-glucose, 1,2,3,4,6 penta-Ogalloyl- $\beta$-D-glucose [11].

And Saussurea lappa L. has various terpenes that mainly have antitumor properties and anti-infammatory, such as costunolide, dihydrocostunolide, 12 - methoxydihydrocostunolide, dihydrocostus lactone, dehydrocostus lactone, $\alpha$-hydroxydehydrocostus lactone, $\beta$-hydroxydehydrocos [12]. Than we developed gallic acid and costunolide in the Gardi patch.

The figure 1 shows the results of the TLC in Gardi patch.
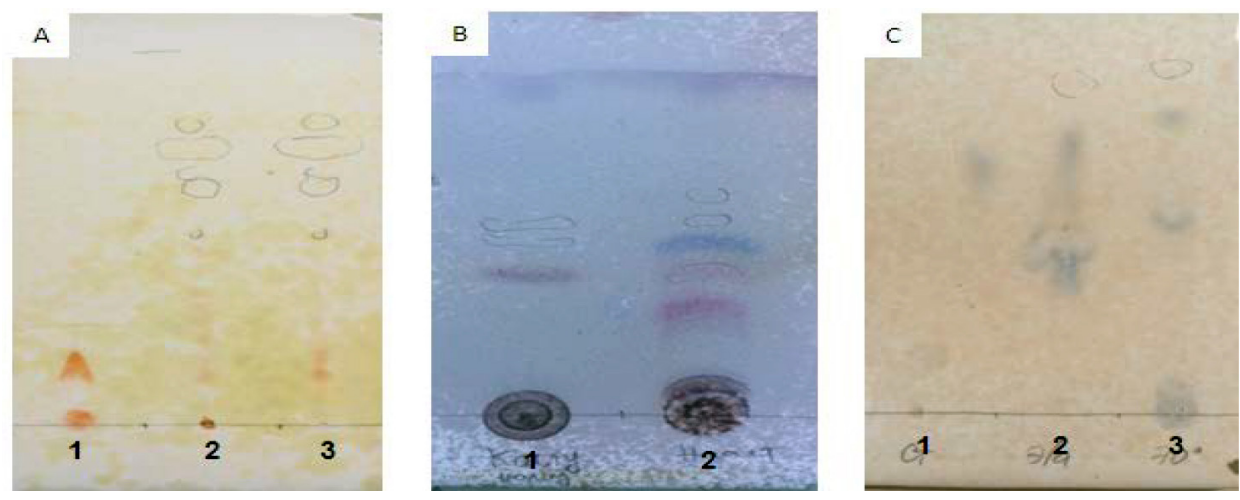

Figure1. TLC of Gardi patch

Note: A- Spray with Dragendorff reagent (1- alkaloid, 2-3- extract of Gardi patch), B$5 \%$ spray with vanilin-sulfuric acid reagent (1- Costunolide, 2- extract of Gardi patch), C - spray with $3 \%$ ferric chloride reagent (1gallic acid, 2-3- extract of Gardi patch).

We developed alkaloid, costunolide and gallic acid in Gardi patch and Rf values were

\section{$0.13,0.39$ and 0.65 respectively.}

\section{Total phenolic contents}

The total phenolic contents were measured by Folin Ciocalteu reagent in terms of gallic acid equivalent (the stander curve equation: $y$ $=110.77 \mathrm{x}-0.0736, \mathrm{r} 2=0.983)$. 


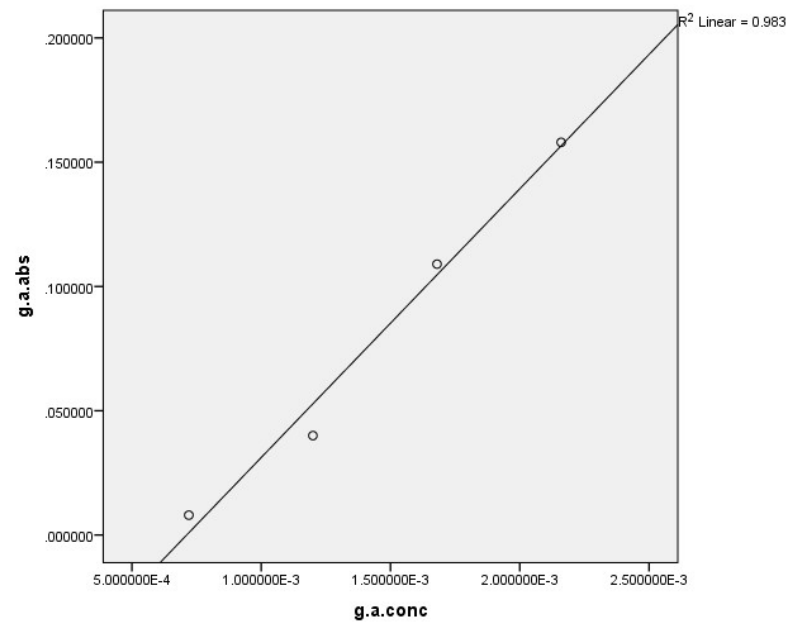

Figure2. Gallic acid calibration curve

Table1. Total phenolic compounds in the extracts of the Gardi patch

\begin{tabular}{|c|c|c|c|}
\hline № & Biological activity substance & Values obtained (\%) & Average (\%) \\
\hline 1 & \multirow{3}{*}{ Flavonoids } & 0.518 & \multirow{3}{*}{$0.567 \pm 0.043$} \\
\hline 2 & & 0.6 & \\
\hline 3 & & 0.585 & \\
\hline
\end{tabular}

\section{Result of HPLC}

The retention time of aconitine was 62.98 minutes.
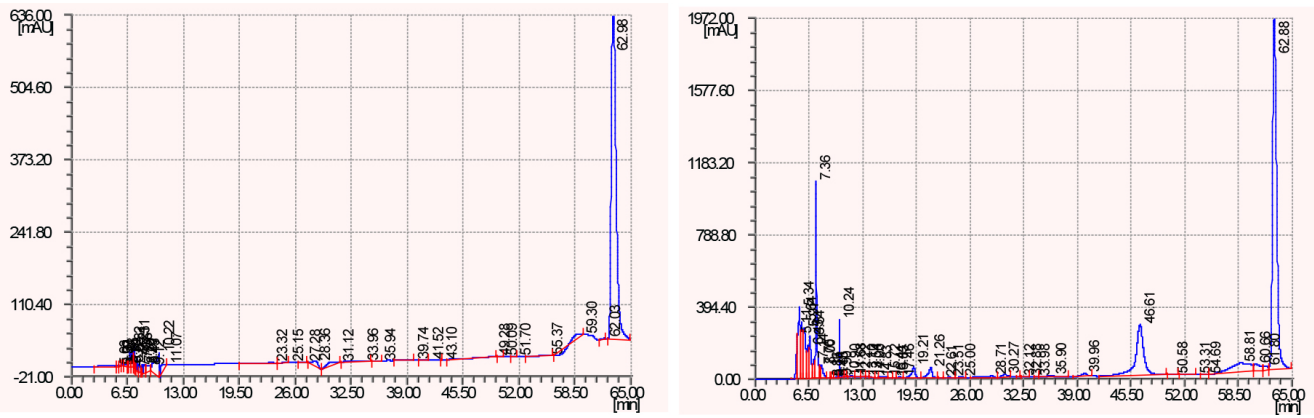

Figure 3. HPLC chromatograms of aconitine and Gardi patch

Table 2. Result of aconitine in Gardi patch by HPLC

\begin{tabular}{cccc}
\hline & Retention time, minutes & Area & Content, $\%$ \\
\hline 1 & 62.88 & 6755892.6 & 0.16 \\
\hline 2 & 63.28 & 6820061.7 & 0.17 \\
\hline 3 & 62.98 & 7125668.8 & 0.178 \\
\hline Average & $63.04 \pm 0.2$ & & $0.169 \pm 0.009$ \\
\hline
\end{tabular}


The retention time was $63.04 \pm 0.2$ minutes

Gardi patch. and amount of aconitine was $0.169 \pm 0.009 \%$ in

\section{Result of physicochemical properties and quality parameters}

We determined physicochemical properties and microbiological parameters by Mongolian

National First Pharmacopoeia methods.

Table3. The quality parameters of Gardi patch

\begin{tabular}{|c|c|c|c|}
\hline № & Quality parameters & Methods & Result \\
\hline 1 & Outer appearance & Organoleptic & $\begin{array}{l}\text { Gardi patch was light brown colour, } \\
\text { unusual smell and rectangular shape }\end{array}$ \\
\hline 2 & Qualitative & TLC & Gallic acid, alkaloid, costunolide \\
\hline 3 & Average weight & Weight method & $3.969 \pm 0.196 \mathrm{~g}$ \\
\hline 4 & Moisture & Weight method & $27.28 \pm 0.65 \%$ \\
\hline 5 & Thickness & SATA 91511 & $0.83 \pm 0.2 \mathrm{~mm}$ \\
\hline 6 & Total phenolic & UV spectrophotometer & $0.567 \pm 0.043 \%$ \\
\hline 7 & Content of aconitine & HPLC & $0.169 \pm 0.009 \%$ \\
\hline 8 & Total bacteria & \multirow{7}{*}{ Microbiological method } & $1 \times 10^{3}$ \\
\hline 9 & Total mould & & Not detected \\
\hline 10 & Escherichia coli & & Not detected \\
\hline 11 & Salmonella & & Not detected \\
\hline 12 & Pseudomonas aeruginosa & & Not detected \\
\hline 13 & Staphylococcus aureus & & Not detected \\
\hline 14 & Enterobacter & & Not detected \\
\hline
\end{tabular}

\section{CONCLUSION}

We detected some quality and safety parameters of Gardi patch and such as suitable conditions of TLC to reveal alkaloid, gallic acid and costunolide. The content of aconitine was $0.169 \pm 0.009 \%$ and the total phenolic content was $7.8 \pm 0.67 \%$ in the Gardi patch. Quality and safety parameters of "Gardi" transdermal patch was determined as: moisture $27.28 \pm 0.65$ $\%$, average weight $3.969 \pm 0.196 \mathrm{~g}$, thickness $0.83 \pm 0.2 \mathrm{~mm}$, total bacteria $1 \times 103$, mould, Escherichia coli, Salmonella, Pseudomonas aeruginosa, Staphylococcus aureus and Enterobacter were not detected in "Gardi" transdermal patch. This study is continuing. 


\section{REFERENCES}

1. Ганбаяр Я. Монгол эмийн жорын гарын авлага. Улаанбаатар. 2001.

2. Олдох С, Цэрэнцоо Б, Батхуяг П. Монгол эмийн судлал. Улаанбаатар. 2009.

3. Ууганбаяр Б. Уламжлалт гарьд - 5 жорын фармакологийн судалгааны зарим асуудалд. АУ-ны докторын зэрэг горилсон нэг сэдэвт бүтээл. Улаанбаатар: ЭруҮл мэндийн шинжллэх ухааны их сургууль; 2013.

4. Сугаржав Э. Уламжлалт гарьд-5 жорын фитохимийн судалгааны үр дүн. ХУны магистрын зэрэг горилсон нэг сэдэвт бүтээл. Улаанбаатар: Монгол улсын их сургууль: 2013.

5. Монгол улсын үндэсний фармакопей. Улаанбаатар: 2011

6. Chinese pharmacopoeia commission. Pharmacopoeia of the poeple`s republic of China. Vol 1: People 's Medical Publishing House; 2005.

7. Folin $O$, Ciocalteu V. On tyrosine and tryptophane determinations in proteins. J. Biol. Chem. 1927 [accessed 2016 Sep 01]; 73: 627-650. Available from: http://devbiodev. wustl.edu/InfoSource/ISPDFs/Folin\%201927.pdf

8. Gabriel AA, Joe AV, Patrick E.D. Folin-Ciocalteau Reagent for Polyphenolic Assay. International Journal of Food Science, Nutrition and Dietetics. 2014 [accessed 2016 Sep 01]; 3(801):3-11. Available from: https://www.researchgate.net/publication/268811626

9. Eric N, Yanyan X, Yubo L et al. A review on phytochemistry, pharmacology and toxicology studies of Aconitum. Journal of Pharmacy and Pharmacology. 2015; 67(1):1-19.

10. Wang $Z$ et al. Quantitative determination of diterpenoid alkaloids in four species of Aconitum by HPLC. J Pharm Biomed Anal. 2006; 40: 1031-1034

11. Rathinamoorthy R and Thilagavathi G. Terminalia Chebula-Review on Pharmacological and Biochemical Studies. International Journal of PharmTech Research. 2014. 6(1); 97116

12. Kulsoom Z, Shaista T, Sidra S. A review of therapeutic potential of Saussurea lappa-An endangered plant from Himalaya. Asian Pacific Journal of Tropical Medicine. 2014; 7(1): 60-69. 